\title{
Current evidence of SARS-CoV-2 vertical transmission: an integrative review
}

\author{
(1D) Lisiane Vital de Oliveira ${ }^{1}$ \\ Camila Radelley Azevedo Costa da Silva² \\ (iD Lorenna Peixoto Lopes ${ }^{1,2}$ \\ (iD) Isabela Karine Rodrigues Agra ${ }^{1,2}$
}

1. Faculdade de Medicina - Centro Universitário Cesmac, Maceió, AL, Brasil 2. Faculdade de Medicina - Universidade Federal de Alagoas, Maceió, AL, Brasil

http://dx.doi.org/10.1590/1806-9282.66.S2.130

\section{SUMMARY}

OBJECTIVE: To review the current scientific evidence of vertical transmission related to coronavirus disease 2019 (COVID-19).

METHODS: An integrative review was performed by two independent researchers, based on the literature available in the MEDLINE (via PubMed) and LILACS databases, using the descriptors "pregnancy" AND "COVID-19" AND "vertical transmission". This search included case reports or case series published up until $77^{\text {th }}$ June 2020 in English or Portuguese. After reading the articles available in their entirety, those related specifically to the potential risks of vertical transmission of COVID-19 during pregnancy were selected. We initially found a total of 57 articles; 26 were carefully screened and 15 were finally selected.

RESULTS: Pregnancy can make women more susceptible to infections, especially by viral pathogens, given the various physiological and immunological changes that occur to maintain maternal-fetal balance. It is speculated that the fetus may be a possible target for COVID-19. Few studies (3 out of 15) in our analysis have found positive results for SARS-CoV-2 in fetal membranes, placenta, and in newborns right after birth. Additionally, no difference was noticed when comparing different modes of delivery, and seems reasonable to assume that pregnant women with stable clinical conditions can be encouraged for vaginal delivery.

CONCLUSION: Further studies with a great number of cases are warranted to elucidate whether the virus may be vertically transmitted to the fetus and if any maternal conditions can influence that. Our findings seem to demonstrate that vertical transmission is possible but quite unusual.

KEYWORDS: Pregnancy. Coronavirus Infections. Infectious Disease Transmission, Vertical.

\section{INTRODUCTION}

The current coronavirus disease (COVID-19) pandemic emerged in China at the end of 2019'1 . Although this new severe acute respiratory syndrome coronavirus (SARS-CoV-2) has a generally low fatality rate calculated at $2.3 \%$, it is highly contagious, causing more deaths in absolute numbers than other similar specimens ${ }^{2}$. So far, there is still great concern about the possible consequences of this infection in pregnancy.

Data published up until recently indicate that pregnant women do not seem to be at a higher risk of developing COVID-19 compared to the general population $^{3}$. However, this group may have a greater risk of obstetric morbidity associated with the virus infection,

DATE OF SUBMISSION: 28-Jun-2020

DATE OF ACCEPTANCE: 11-Jul-2020

CORRESPONDING AUTHOR: Isabela Karine Rodrigues Agra

Faculdade de Medicina da Universidade Federal de Alagoas (Ufal) - Campus A. C. Simões, Av. Lourival Melo Mota s/n

Tabuleiro dos Martins - Maceió - Alagoas - CEP: 57072-900 -Tel.: (82) 3214-1858

E-mail: agraisabela@gmail.com 
since small series of cases reported an increased risk of premature birth, rupture of membranes, placental abruption, and fetal distress ${ }^{4,5}$. Moreover, in low- to middle-resource countries, evidence suggests the possibility of increased postpartum death rates, possibly due to inadequate prenatal and postnatal care ${ }^{6}$.

The possibility of transmission from mother to fetus in COVID-19 is considered controversial, as the number of confirmed cases for the disease increases all over the world ${ }^{7}$. Reports of neonatal infection shortly after birth may suggest transplacental infection (vertical transmission) or horizontal transmission via direct surface contact at delivery or during breastfeeding ${ }^{8}$. Furthermore, if this route of intrauterine infection is proven possible, it is also important to determine the moment of the pregnancy when the virus crossed the placenta, in order to establish the possibility of injuries to the fetal organ formation and their well-being.

Considering the lack of consensus on vertical transmission in SARS-CoV-2 infection, in this review, we assembled the most recent studies involving this subject in an attempt to summarize the current understanding of congenital infection by COVID-19.

\section{METHODS}

This integrative literature review was conducted in the Medical Literature Analysis and Retrieval System on-line (Medline, through access to the PubMed) and in the Latin America and Caribbean Health Sciences Literature (Lilacs) databases. The descriptors - and their combination in Portuguese and English - used were "pregnancy" and "COVID-19" and "vertical transmission", crossed using the Boolean operator "AND". This search included articles published up until $17^{\text {th }}$ June 2020.

The inclusion criteria defined to first select articles were case series and case reports published in English or Portuguese - review articles, short communications, dissertations, and management guidelines were not included. Then, studies that were not available on the internet databases in its entirety were excluded. After reading the full extent of the articles, those studies that did not address specifically the vertical transmission or congenital infection by COVID-19 were also excluded. For that, two independent researchers performed the search strategy in the scientific databases and, if there were disagreements regarding the final inclusion, a third senior researcher was consulted.

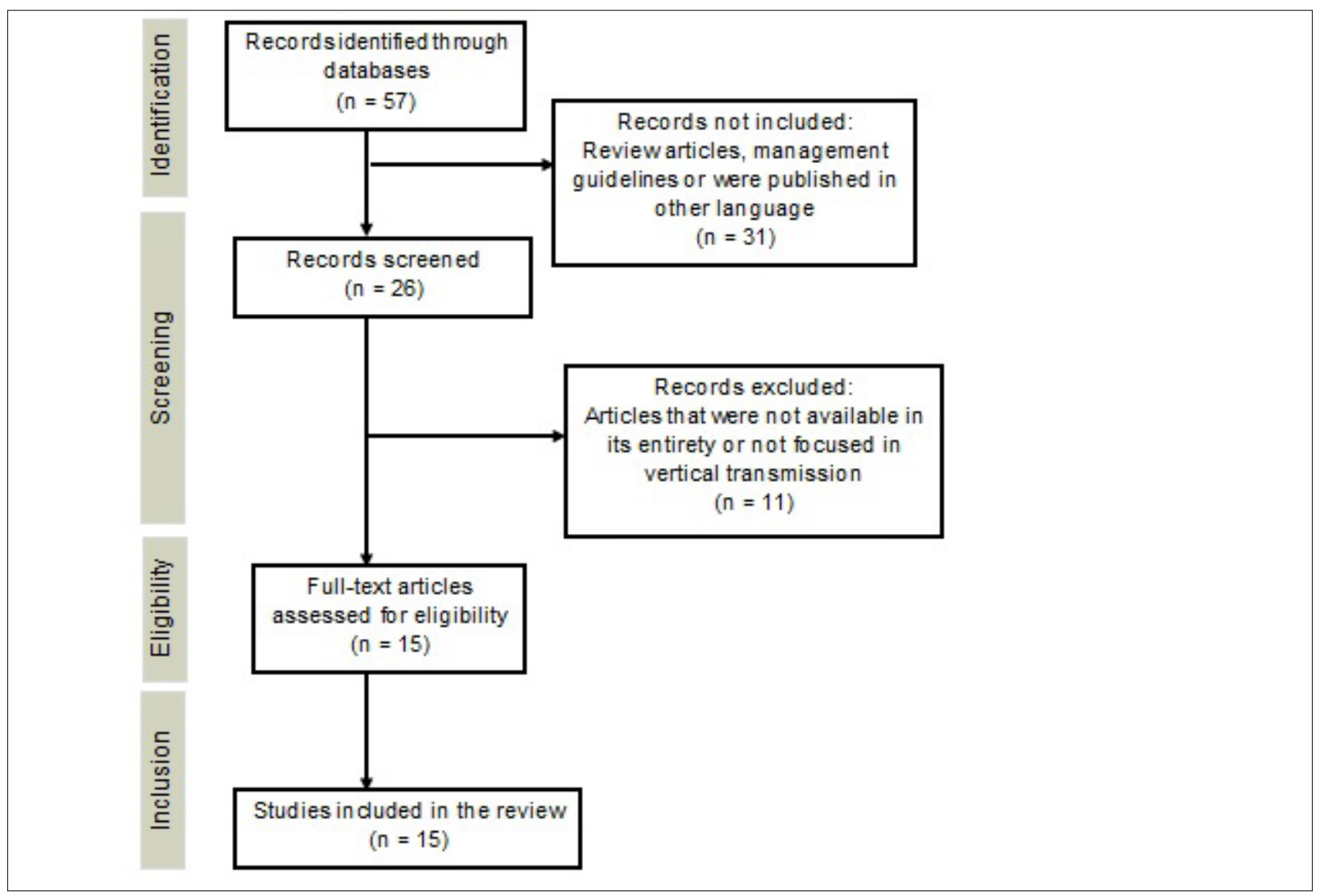

FIGURE 1. PRISMA 2009 FLOW DIAGRAM FOR ARTICLE'S INCLUSION ON VERTICAL TRANSMISSION OF COVID-19 


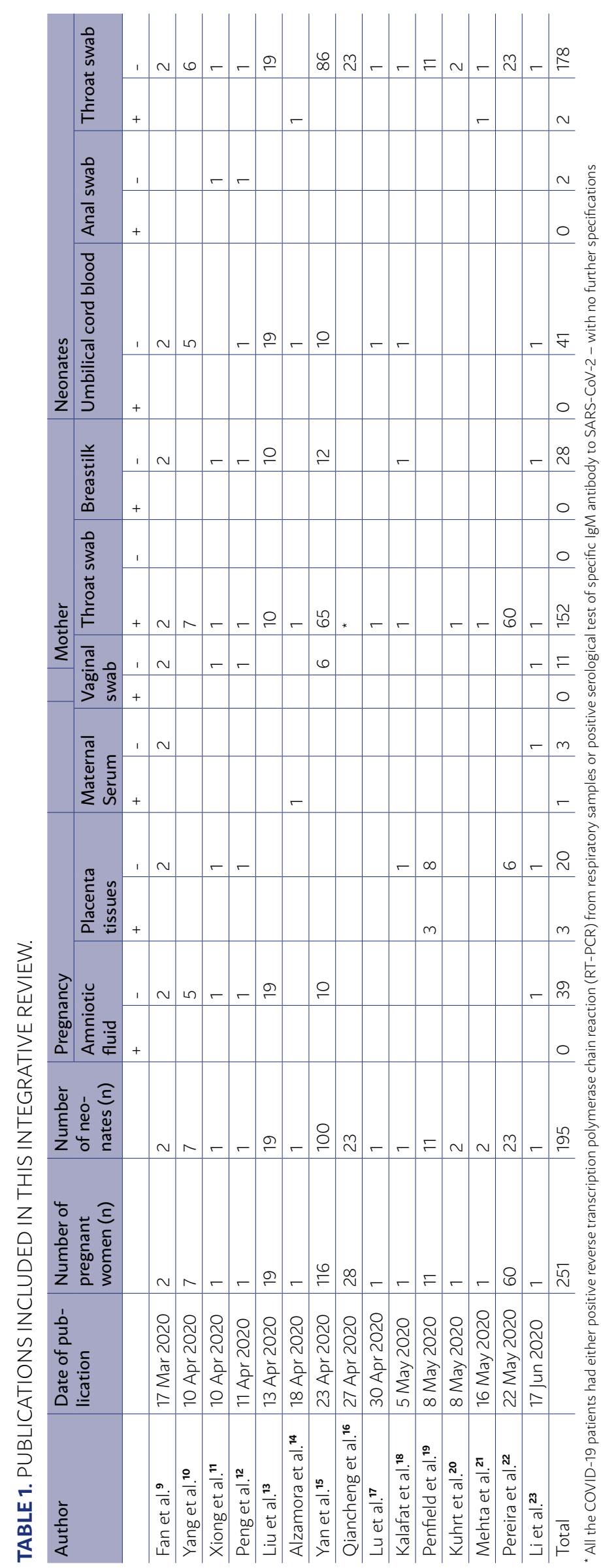

This review was performed according to a standard protocol for systematic reviews, which was based on the methodological manuals of the Preferred Reporting Items for Systematic Reviews and Meta-Analyses (PRISMA). We initially found a total of 57 articles; 26 were carefully screened and, according to the inclusion and exclusion criteria adopted, 15 papers were finally selected. Figure 1 summarizes the studies' selection.

\section{RESULTS AND DISCUSSION}

The articles selected are shown in Table 1, which summarizes their main information and findings regarding maternal and neonatal exam results ${ }^{9-23}$.

Pregnancy consists of complex physiological and immunological processes that can make this period more susceptible to infections, including by viral pathogens ${ }^{24}$. The maternal immune response may play a crucial role in the pathophysiology of coronavirus infections since important changes need to happen to ensure maternal-fetal balance. For this, throughout gestation, the female body changes from a pro-inflammatory to an anti-inflammatory state, depending on the needs of the fetus ${ }^{25}$.

Although SARS-CoV-2 infection may cause a cytokine storm and induces a more severe inflammatory state in the maternal-fetal placental interface ${ }^{25}$, the available scientific evidence is still inconclusive regarding aspects of vertical transmission during pregnancy.

Lamouroux et al. ${ }^{26}$ and Mahyuddin et al..$^{27}$, mention that many microorganisms are able to violate the maternal immune system barrier through the placenta and result in severe fetal consequences. Viruses can exert dynamic fluctuations in the immune environment of the placenta throughout pregnancy and contribute to changes in fetal susceptibility ${ }^{27}$. Thus, SARS-COV-2 has also become a major concern in pregnancy, although few case reports with a small number of subjects have shown positive results in placental tissue or in newborns ${ }^{14,19,21}$.

Penfield et al. ${ }^{19}$ published the first study that found the presence of viral RNA in the placenta/membranes. Details regarding the histological examination of the placentas (3 out of 11) that tested positive (for PCR analysis of placental tissue or membranes) were not provided. Besides that, none of the 11 neonates tested positive right after birth or in the first 5 days of life. The authors also mention that given the mixing of maternal and fetal fluids and tissue at the time of 
delivery, the origin of the detected SARS-CoV-2 RNA in their series is unclear.

Low cellular expression of the angiotensin-converting enzyme 2 (ACE2) on the trophoblast, especially in the first trimester, may explain the small amount of evidence attesting vertical transmission. It has been shown that ACE2 is a functional receptor for SARS-CoV-2 infection $^{28}$. In addition, COVID-19 does not appear to have sufficient evolution to use perivascular cluster cells (PV1) to overcome the immune system and affect the fetus during pregnancy ${ }^{29}$.

Rajewska et al..$^{30}$ and Panahi et al. ${ }^{31}$ describe that most of the evidence, so far, does not suggest vertical transmission and that the reported cases were possibly infected after pregnancy and delivery. In many studies, RT-PCR tests in neonates were performed several hours after birth, when horizontal transmission cannot be ruled out.

Thus, much has been discussed about the mode of delivery for pregnant women with COVID-19, which should be guided mainly according to the maternal-fetal hemodynamic status. Therefore, different recommendations for cesarean delivery have been described, even in mild cases, initially assuming that the newborn's passage through the birth canal could increase their chances of viral infection.

However, recent evidence failed to prove the benefits of cesarean compared to vaginal birth in stable cases $^{14}$. It is important to highlight that the choice of the mode of delivery must take into account the maternal clinical condition, signs of fetal distress, gestational age, and maternal complications ${ }^{11}$. Corroborating this, Pereira et al. ${ }^{22}$ evidenced that during the study period, 18 of the women included in their analysis $(78 \%)$ delivered vaginally. All newborns tested negative for SARS-CoV-2 and none of them were infected during breastfeeding. No SARS-CoV-2 was detected in placental tissue. Accordingly, it seems reasonable to assume that pregnant women and their fetuses with stable clinical conditions can strongly benefit from this mode of delivery ${ }^{17,19}$.

Zimmermann and Curtis ${ }^{32}$ noticed that even with strict infection control and prevention procedures during and after cesarean delivery, four neonates tested positive for SARS-CoV-2 (one healthy newborn and three who presented pneumonia), and three of them also expressed IgM and IgG antibodies at birth, suggesting the possibility of vertical transmission. Zeng et al. ${ }^{33}$ corroborate that with the report of six neonates - all born by cesarean delivery in an isolated room with negative pressure and immediate separation from their mothers - that exhibited high concentrations of IgG and IgM antibodies right after birth, as well as high inflammatory levels of interleukin-6.

It is believed that maternal IgM antibodies do not cross the placental barrier because it is a macromolecule when compared to IgG, which is passively transferred through the mother's placenta to the fetus ${ }^{26,33,34}$. Therefore, it is speculated that the IgM presented in the newborn is produced by the baby when in contact with the virus that has possibly crossed the placental barrier, since the IgM molecule usually does not appear until 3-7 days after infection ${ }^{33,34}$.

This subject still remains questionable, since Xiong et al. ${ }^{11}$ and Alzamora et al. ${ }^{14}$, on the other hand, reported negative IgG and IgM serological results in all the newborns studied right after birth. Therefore, the maternal-fetal transmission of SARS-CoV-2 is still a controversial subject.

\section{CONCLUSION}

Further studies with a great number of cases are warranted to elucidate whether the virus may be vertically transmitted to the fetus and if any maternal conditions can influence that. Our findings seem to demonstrate that vertical transmission is possible but quite unusual. Complications related to newborns are apparently more related to the aspects of prematurity than to the impairment caused by the virus itself.

Since uncertainties remain without robust scientific answers, infection control will be the basis for preventing further spread among pregnant women, combined with social distance and universal testing in areas of high prevalence ${ }^{27}$.

\section{Conflicts of interest}

The authors declare that they have no conflicts of interest.

\section{Author's Contribution}

Lisiane V. de Oliveira: Data management/analysis, manuscript writing

Camila R. A. C. da Silva: Data management/analysis, manuscript writing

Lorenna P. Lopes: Project development, data management/analysis, manuscript writing

Isabela K. R. Agra: Project development, data management/analysis, manuscript editing 


\section{RESUMO}

OBJETIVO: Revisar as evidências científicas atuais sobre a transmissão vertical relacionada à infecção pelo novo coronavírus 2019 (COVID-19).

MÉTODOS: Uma revisão integrativa foi realizada por dois pesquisadores independentes, com base na literatura disponível nas bases de dados Medline (via PubMed) e Lilacs, utilizando os descritores "gravidez" e "COVID-19" e "transmissão vertical". Esta pesquisa incluiu relatos de caso ou séries de casos publicados até 17 de junho de 2020, em inglês ou português. Após a leitura integral dos artigos, foram selecionados aqueles relacionados especificamente aos riscos potenciais da transmissão vertical do COVID-19 durante a gravidez. Encontramos inicialmente um total de 57 artigos; 26 foram cuidadosamente analisados e 15 artigos foram finalmente selecionados.

RESULTADOS: A gravidez pode tornar as mulheres mais suscetíveis a infecções, principalmente patógenos virais, dadas as várias alterações fisiológicas e imunológicas que ocorrem para manter o equilíbrio materno-fetal. Especula-se que o feto possa ser um possível alvo para a COVID-19. Poucos estudos (3 em 15) em nossa análise encontraram resultados positivos para Sars-CoV-2 em membranas fetais, placenta e em recém-nascidos logo após o nascimento. Além disso, nenhuma diferença foi observada ao comparar diferentes tipos de parto e parece razoável supor que mulheres grávidas com condições clínicas estáveis podem ser incentivadas para o parto vaginal.

CONCLUSÃo: Mais estudos com maior número de casos são necessários para elucidar se o vírus pode ser transmitido verticalmente ao feto e se alguma condição materna pode influenciar isso. Nossas descobertas parecem demonstrar que a transmissão vertical é possivel, mas bastante incomum.

PALAVRAS-CHAVE: Gravidez. Infecções por coronavírus. Transmissão vertical de doença infecciosa.

\section{REFERENCES}

1. Anesi GL. Coronavirus disease 2019 (COVID-19): critical care and airway management issues. UpToDate Jun 2020. [cited 2020 Jul 7]. Available from: https://www.uptodate.com/contents/ coronavirus-disease-2019-COVID-19-critical-care-issues

2. Wang L, Shi Y, Xiao T, Fu J, Feng X, Mu D, et al; Working Committee on Perinatal and Neonatal Management for the Prevention and Control of the 2019 Novel Coronavirus Infection. Chinese expert consensus on the perinatal and neonatal management for the prevention and control of the 2019 novel coronavirus infection (First edition). Ann Transl Med. 2020;8(3):47.

3. Dotters-Katz SK, Hughes BL. Considerations for obstetric care during the COVID-19 pandemic. Am J Perinatol. 2020;37(8):773-9.

4. Zhu H, Wang L, Fang C, Peng S, Zhang L, Chang G, et al. Clinical analysis of 10 neonates born to mothers with 2019-nCoV pneumonia. Transl Pediatr. 2020;9(1):51-60

5. Schwartz DA, Graham AL. Potential maternal and infant outcomes from (Wuhan) coronavirus 2019-nCoV infecting pregnant women: lessons from SARS, MERS, and other human coronavirus infections. Viruses. 2020;12(2):194.

6. Amorim MMR, Takemoto MLS, Fonseca EB. Maternal deaths with coronavirus disease 2019: a different outcome from low-to middle-resource. Am | Obstet Gynecol. 2020;S0002-9378(20)30471-3.

7. Knight M, Bunch K, Vousden N, Morris E, Simpson N, Gale C, et al; UK Obstetric Surveillance System SARS-CoV-2 Infection in Pregnancy Collaborative Group. Characteristics and outcomes of pregnant women admitted to hospital with confirmed SARS-CoV-2 infection in the UK: a national population based cohort study. BMJ. 2020;369:m2107.

8. Tosone G, Maraolo AE, Mascolo S, Palmiero G, Tambaro O, Orlando R Vertical hepatitis $C$ virus transmission: main questions and answers. World | Hepatol. 2014;6(8):538-48.

9. Fan $C$, Lei D, Fang $C$, Li C, Wang M, Liu Y, et al. Perinatal transmission of COVID-19 associated SARS-CoV-2: should we worry? Clin Infect Dis. 2020; ciaa226.

10. Yang P, Wang X, Liu P, Wei C, He B, Zheng J, et al. Clinical characteristics and risk assessment of newborns born to mothers with COVID-19. I Clin Virol. 2020;127:104356

11. Xiong $X$, Wei $H$, Zhan Z, Chang |, Ma X, Gao X, et al. Vaginal delivery report of a healthy neonate born to a convalescent mother with COVID-19. J Med Virol. 2020;10.1002/jmv.25857.

12. Peng Z, Wang J, Mo Y, Duan W, Xiang G, Yi M. Unlikely SARS-CoV-2 vertical transmission from mother to child: a case report. | Infect Public Health. 2020;13(5):818-20.
13. Liu W, Wang |, Li W, Zhou Z, Liu S, Rong Z, et al. Clinical characteristics of 19 neonates born to mothers with COVID-19. Front Med. 2020;14(2):193-8.

14. Alzamora MC, Paredes T, Caceres $D$, Webb CM, Valdez LM, La Rosa $M$. Severe COVID-19 during pregnancy and possible vertical transmission. Am J Perinatol. 2020;37(8):861-5.

15. Yan J, Guo J, Fan C, Juan J, Yu X, Li J, et al. Coronavirus disease 2019 in pregnant women: a report based on 116 cases. Am | Obstet Gynecol. 2020;223(1):111.e1-111.e14.

16. Qiancheng $X$, Jian S, Lingling $P$, Lei H, Xiaogan |, Weihua L, et al; sixth batch of Anhui medical team aiding Wuhan for COVID-19. Coronavirus disease 2019 in pregnancy. Int | Infect Dis. 2020;95:376-83.

17. Lu D, Sang L, Du S, Li T, Chang Y, Yang XA. Asymptomatic COVID-19 infection in late pregnancy indicated no vertical transmission. | Med Virol. 2020;10.1002/jmv.25927.

18. Kalafat E, Yaprak E, Cinar G, Varli B, Ozisik S, Uzun C, et al. Lung ultrasound and computed tomographic findings in pregnant woman with COVID-19. Ultrasound Obstet Gynecol. 2020;55(6):835-7.

19. Penfield CA, Brubaker SG, Limaye MA, Lighter J, Ratner AJ, Thomas KM, et al. Detection of SARS-COV-2 in placental and fetal membrane samples. Am | Obstet Gynecol MFM. 2020;100133.

20. Kuhrt K, McMicking I, Nanda S, Nelson-Piercy C, Shennan A. Placental abruption in a twin pregnancy at 32 weeks' gestation complicated by COVID-19, without vertical transmission to the babies. Am J Obstet Gynecol. 2020;100135.

21. Mehta H, Ivanovis S, Cronin A, VanBrunt L, Mistry N, Miller R, et al. Novel coronavirus-related acute respiratory distress syndrome in a patient with twin pregnancy: a case report. Case Rep Womens Health. 2020;27:e00220.

22. Pereira A, Cruz-Melguizo S, Adien M, Fuentes L, Marin E, Perez-Medina T. Clinical course of coronavirus disease-2019 in pregnancy. Acta Obstet Gynecol Scand. 2020;99(7):839-47.

23. Li Y, Zhao R, Zheng S, Chen $X$, Wang |, Sheng $X$, et al. Lack of vertical transmission of severe acute respiratory syndrome coronavirus 2, China. Case Infect Dis. 2020;26(6):1335-6.

24. Zaigham M, Andersson O. Maternal and perinatal outcomes with COVID19: a systematic review of 108 pregnancies. Acta Obstet Gynecol Scand. 2020;99(7):823-9.

25. Silva CRAC, Oliveira LV, Lopes LP, Santos WAGD, Agra IKR. Immunological aspects of coronavirus disease during pregnancy: an integrative review. Rev Assoc Med Bras. 2020;66(5):696-700.

26. Lamouroux A, Attie-Bitach T, Martinovic ), Leruez-Ville M, Ville Y. Evidence 
for and against vertical transmission for severe acute respiratory syndrome coronavirus 2. Am J Obstet Gynecol. 2020;223(1):91.e1-91.e4.

27. Mahyuddin AP, Kanneganti, A, Wong J, Dimri PS, Su LL, Biswas A, et al. Mechanisms and evidence of vertical transmission of infections in pregnancy including SARS-CoV-2. Prenat Diagn. 2020;10.1002/pd.5765.

28. Hoffmann M, Kleine-Weber H, Schroeder S, Krüger N, Herrler T, Erichsen S, et al. SARS-CoV-2 cell entry depends on ACE2 and TMPRSS2 and is blocked by a clinically proven protease inhibitor. Cell. 2020;181(2):271-80.

29. Zheng QL, Duan T, Jin LP. Single-cell RNA expression profiling of ACE2 and $A X L$ in the human maternal-fetal interface. Reprod Develop Med. 2020;4(1):7-10.

30. Rajewska A, Mikolajek-Bedner W, Lebdowicz-Knul J, Sokolowska M,
Kwiatkowski S, Torbé A. COVID-19 and pregnancy: where are we now? A review. J Perinat Med. 2020;48(5):428-34.

31. Panahi L, Amari M, Pouy S. Risks of novel coronavirus disease (COVID-19) in pregnancy: a narrative review. Arch Acad Emerg Med. 2020;8(1):e34.

32. Zimmermann P, Curtis N. COVID-19 in children, pregnancy and neonates: a review of epidemiologic and clinical features. Pediatr Infect Dis J. 2020;39(6):469-77.

33. Zeng H, Xu C, Fan |, Tang Y, Deng Q, Zhang W, et al. Antibodies in infants born to mothers with COVID-19 pneumonia. JAMA. 2020;323(18):1848-9.

34. Dong L, Tian J, He S, Zhu C, Wang J, Liu C, et al. Possible vertical transmission of SARS-CoV-2 from an infected mother to her newborn. JAMA. 2020;323(18):1846-8. 